\title{
Conception and Regulation of the Political of Law of Corruption Eradication in Indonesia Reform Era
}

\author{
Dr. Roberts Kennedy, S.I.K., S.H., M.Hum \\ Faculty of Law, Batam University, Indonesia
}

http://dx.doi.org/10.18415/ijmmu.v6i10.904

\begin{abstract}
Corruption is not a new crime, but a very quaint old crime. Corruption does not only happen in Indonesia, corruption also occurs in other countries. In fact, this is now regarded as corruption is an international problem. Combating corruption always get more attention than other crimes. In general, these criminal acts are not only result in losses to the state (state finances), but may result in a very broad impact, both in the social, economic, security, political, and cultural.
\end{abstract}

Keywords: Political of Law; Corruption Eradication; Indonesia Reform Era

\section{Introduction}

As far as can be observed, the practice of corruption is so widespread in Indonesia ${ }^{1}$. So bad, the form of abuse of authority is actually considered a common practice. Seeing this condition, it is not surprising that in the last three years the Political and Economic Risk Consultancy (PERC) research institute has always put Indonesia as the champion of corruption in Asia. Similar predictions also come

\footnotetext{
${ }^{1}$ On an international scale, measurement of public perceptions is carried out by various institutions, one of which is Transparency International through a corruption perception index survey (perceptions of corruption index, GPA) that assesses public perceptions of the existence of corruption based on a combination of several surveys from various institutions. This survey still puts Indonesia in a position that is still low despite the tendency to increase numbers. In 2011, Indonesia's GPA was ranked 100 out of 183 countries with a score of 3.0 (up about 0.2 compared to 2010 GPA or 1.0 since 2004).

Another thing is indicated by the global corruption barometer (GCB) index in 2010. According to GCB 2010, some respondents stated that they had made bribe payments. The number reached 18 percent. The higher the index in an institution, the more perceived the institution is corrupt. The GCB index provides the highest score with an index value of 3.6 for the legislative body, followed by police institutions and political parties with an index of 3.5. The Judiciary is given a 3.3 index, followed by executive officials (3.2).
} 
from Transparency International, which always places Indonesia as one of the most corrupt countries in the world ${ }^{2}$.

Eradication of corruption always gets greater attention than other criminal acts. In general, this criminal offense not only results in state losses (state finances), but can have a very broad impact, both in the social, economic, security, political and cultural fields. If corruption becomes a culture, this crime can damage the values of democracy and morality of a nation. In fact, according to Romli Atmasasmita, corruption in addition to suffering the people also violates the economic and social rights of the people ${ }^{3}$.

According to Edward Omar Sharif Hiariej, since the onset of reform, the issue of eradicating corruption has always been a central theme in law enforcement in Indonesia. Corruption in the viewpoint of criminal law is an international crime that has character and character as an extraordinary crime ${ }^{4}$. There are at least four characteristics and characteristics of corruption crimes as extraordinary crime.

First, corruption is organized crime that is carried out systematically. Briefly Francis Ianni defines organized crime - such as the Mafia in Italy, the Yakuza in Japan, the Triad in China and the Cartel in Colombia - as crimes committed by non-formal organizations with irrational structures to double profits with the most efficient work possible. Second, corruption is usually done with difficult modus operandi so it is not easy to prove it $^{5}$.

Third, corruption is always related to power. In the context of the nature and characteristics of this third corruption, we recognize a kind of postulate proposed by Lord Acton that power tends to be corrupt and absolute power, absolute corruption as well. Fourth, corruption is a crime related to the rice of many people because the state finances that can be harmed are very beneficial to improve people's welfare. According to World Bank records as of June 2007 it is estimated that the amount of state assets in Indonesia that have been corrupted is US \$ 15-35 billion. While referring to Danny Leipziger, World Bank Deputy President for Poverty Alleviation and Economic Management, every \$100 million refundable corruption can build 240 kilometers of roads, immunize 4 million babies and provide clean water to 250 thousand homes ${ }^{6}$.

\section{Discussion}

\subsection{The Reformation era and the idea of eradicating corruption}

Since the reforms rolled out in $1998^{7}$, followed by the agenda of changes to the $1945^{8}$ Constitution, the government's political will to eradicate corruption crimes has become a real priority

\footnotetext{
2 Saldi Isra, Makalah, Peran Perguruan Tinggi dalam Pemberantasan Korupsi, disampaikan dalam Seminar Sehari "Penanggulangan Tindak Pidana Korupsi Melalui Pendidikan Tinggi Hukum, dan Launching Pembukaan Program Kekhususan Anti-korupsi”, diadakan oleh Fakultas Hukum Universitas Tamansiswa-Padang, di Hotel Inna Muara, Padang, 14 Maret 2009

3 Saldi Isra, Makalah, Peran Perguruan Tinggi dalam Pemberantasan Korupsi, disampaikan dalam Seminar Sehari "Penanggulangan Tindak Pidana Korupsi Melalui Pendidikan Tinggi Hukum, dan Launching Pembukaan Program Kekhususan Anti-korupsi”, diadakan oleh Fakultas Hukum Universitas Tamansiswa-Padang, di Hotel Inna Muara, Padang, 14 Maret 2009

${ }^{4}$ Marwan Effendi, Korupsi dan Strategi Nasional Pencegahan Serta Pemberantasannya, Referensi, Jakarta, 2013, hlm. 31.

${ }^{5}$ Edward Omar Sharif Hiariej, Pembuktian Terbalik Dalam Pengembalian Aset Kejahatan Korupsi, Pidato Pengukuhan Jabatan Guru Besar pada Fakultas Hukum Universitas Gadjah Mada pada tanggal 30 Januari 2012 di Yogyakarta, hlm. 3.

${ }^{6}$ Ibid.

7 The legal reform agenda itself involves at least three things, namely First, the reorganization of government and state institutions as well as a whole starting from the MPR State High Institution to village government institutions, as well as the realignment of all social and political institutions; Second, renewal of the national legal system, including: (a) legislation starting from the constitutional text to village regulations; (b) legal institutional structure; and (c) improving the quality of legal officers and professionals; Third, fostering legal awareness and legal culture, so that respect and compliance with the law become the
} 
program. This reform era came as a result of various problems in the New Order era, including high levels of corruption, economic crisis, crisis of trust and conditions of poor political stability. Corruption too, in the new order era it became endemic among bureaucrats (civil and military). Therefore, in this era corruption eradication is a priority law enforcement program. This can be seen by the issuance of the Republic of Indonesia TAP MPR Number XI / MPR / 1998 concerning the Implementation of Clean and Corruption, Collusion and Nepotism Countries. The TAP MPR is one of the guidelines in order to save and create normalization of national life in accordance with the demands of reform.

For the implementation of the TAP MPR, the government, with the approval of the Indonesian Parliament, enacted Law No. 28 of 1999 concerning the Implementation of a Clean and Free of Corruption, Collusion and Nepotism (Law No. 28/1999) on May 19, 1999. But according to Andi Hamzah did not have the formulation of the offense, making it difficult for the Prosecutor to make an indictment. There are sanctions, but there is no formulation of offenses (definition of offense). There is no definition of offense in the formula, how to prove someone has committed nepotism ${ }^{9}$.

In addition, Law No. 3 of 1971 concerning the Eradication of Corruption Crimes (Law No. $3 / 1971$ ) is considered to have weaknesses and can hinder reform ${ }^{10}$. Therefore Law No. 31/1999 concerning the Eradication of Corruption Crime (Law No. 31/1999) was promulgated on August 16, 1999 and stated Law No. 3/1971 is no longer valid ${ }^{11}$.

daily life of the community and state administrators. See Sumali, Reduksi Kekuasaan Eksekutif di Bidang Peraturan Pengganti Undang-Undang (PERPU), (Malang: UMM Pres, 2003), hlm. 1.

${ }^{8}$ The 1945 Constitution has experienced 4 (four) changes. The contents of the 1945 Constitution experienced more than 300 percent. As an illustration, before a change is made, the text of the 1945 Constitution contains 71 items or articles. However, now, after experiencing 4 (four) changes, the provisions contained in it become 199 items. From the formulation of the original provisions, only 25 items remained that did not change at all. Whereas the rest, which is 174 items, is at all the points of the new provisions in the 1945 Constitution of the Republic of Indonesia

(Jimly Asshiddiqie, Pengantar Ilmu Hukum Tata Negara Jilid II, cet. 1, (Jakarta: Konstitusi Press, 2006), hlm. 2-3)

(Jimly Asshiddiqie, Pengantar Ilmu Hukum Tata Negara Jilid II, cet. 1, (Jakarta: Konstitusi Press, 2006), hlm. 2-3)

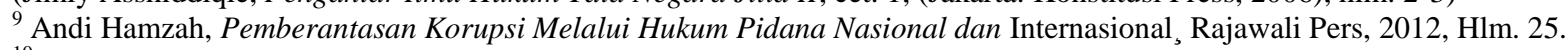

${ }^{10}$ According to Romli Atmasasmita Law Number 3 of 1971 concerning the Eradication of Non-Criminal Corruption there are weaknesses including: a. The weakness in material law lies in the provisions concerning material offenses which are not formally formulated; $b$. The element of state financial losses or the state economy is one of the absolute elements of money that must be proven by the Public Prosecutor; c. The Supreme Court Regulation which affirms, among others, the file of corruption is not proven if the public interest is served, the defendant does not get a profit and the state is not harmed; d. In the formulation of offenses in the matter of criminal sanctions which have set a general maximum and there are no specific minimum limits, so that the Public Prosecutor and Judge can move freely within the minimum general (one day) and maximum maximal limit stipulated in UUTPK 1971. Romli Atamasasmita, "Platform The Philosophy of Eradicating Corruption in Indonesia ", (paper presented at a corruption seminar organized by the Faculty of Law of Trisakti University, Jakarta, August 05, 1999).

11 The articles in Law Number 31 of 1999 can be grouped as follows; First, the offense group that can harm the State's or the country's economy, (as stipulated in Article 2 paragraph (1) and Article 3 of Law Number 31 Year 1999 jo. Law Number 20 Year 2001 concerning Eradication of Corruption Crimes). Second, the bribery offense group, both active (bribing) and passive (bribed) and gratuities. (as stipulated in Article 5 paragraph (1) and paragraph (2), Article 6 paragraph (1) and paragraph (2), Article 11, Article 12 letters a, b, c, and d, and Article 12B paragraph (1) and paragraph (2) of Law Number 31 of 1999 in conjunction with Law Number 20 of 2001 concerning the Eradication of Piddana Corruption). Third, the group for fraud prevention. (as stipulated in Article 8, Article 10 letter a of Law Number 31 Year 1999 jo. Law Number 20 Year 2001 concerning Eradication of Corruption Crimes). Fourth, the offense offense group in positions (knevelarij, extortion). (as stipulated in Article 12 letter e and letter $\mathrm{f}$ of Law Number 31 of 1999 in conjunction with Law Number 20 of 2001 concerning the Eradication of Corruption Crimes). Fifth, forgery fraud groups. (as stipulated in Article 9 of Act Number 31 of 1999 in conjunction with Law Number 20 of 2001 concerning the Eradication of No Criminal Corruption). Sixth, offense groups related to chartering, suppliers and partners. (as stipulated in Article 7 paragraph (1) and paragraph (2), Article 12 letter g and letter i of Law Number 31 Year 1999 jo. Law Number 20 Year 2001 concerning Eradication of Corruption Crimes). Of the 6 (six) groups mentioned above, only 1 (one) group 
If you read the consideration "weigh" Law No. 31/1999, there are at least 3 (three) reasons for establishing this law, namely;

(1) that the crime of corruption is very detrimental to the state's finances or the country's economy and hampers national development, so it must be eradicated in the context of creating a just and prosperous society based on Pancasila and the 1945 Constitution;

(2) that the consequences of criminal acts of corruption that have occurred so far in addition to harming the state's finances or the country's economy, also hamper the growth and sustainability of national development that demands high efficiency;

(3) that Law Number 3 of 1971 concerning the Eradication of Corruption has no longer been in line with the development of legal needs in the community, because it needs to be replaced with a new Law on the Eradication of Corruption Crimes so that it is expected to be more effective in preventing and eradicating acts criminal corruption;

From the formula of consideration "weigh" Law No. 31/1999 above, it is clear that the presence of a new law to eradicate corruption is based on the inability of Law No. 3/1971 as a legal umbrella in eradicating corruption in Indonesia ${ }^{12}$.

\subsection{The Strategic Role of the KPK}

In accordance with the provisions of Article 43 of Law No. 31/1999 as amended by Law Number 20 Year 2001 concerning Amendment to Law Number 31 of 1999 concerning Eradication of Corruption Crime (Law No. 20/2001), it is necessary to establish an Corruption Eradication Commission that is independent of its duties and authority to eradicate corruption ${ }^{13}$. On December 27, 2002 the Law of the Republic of Indonesia Number 30 of 2002 was promulgated concerning the Corruption Eradication Commission (Law No. 30/2002). This law also regulates the authority to coordinate and supervise including conducting investigations, investigations and prosecution of criminal acts of corruption. The replacement of the legal norms for combating corruption above shows the same policy direction, namely improving legal norms so that corruption eradication efforts run well ${ }^{14}$. In addition, Indonesia has also ratified the United Nations Convention on Anti-Corruption in 2003 with Law Number 7 of 2006 concerning Ratification of the Anti-Corruption Convention (United Nations Convention Against Corruption, 2003).

contains elements of detrimental state regulated in 2 articles, namely articles 2 and 3, while 5 other groups consisting of 28 articles are related to deviant behavior from state administrators or civil servants and private parties.

${ }^{12}$ Yopie Morya Immanuel Patiro, Diskresi Pejabat Publik dan Tindak Pidana Korupsi, Keni Media, Bandung, 2012, hlm. 142143.

${ }^{13}$ Apart from the order of Article 43 of Law Number 31 of 1999 concerning Eradication of Corruption Crimes as amended by Law Number 20 Year 2001 concerning Amendment to Law Number 31 of 1999 concerning Eradication of Corruption Crime, the establishment of the Corruption Eradication Commission (KPK ) which can be read in the consideration of "weighing" Law Number 30 of 2002 concerning the Corruption Eradication Commission is also in the context of realizing a just, prosperous, and prosperous society based on Pancasila and the 1945 Constitution of the Republic of Indonesia, eradicating corruption what has happened until now cannot be optimally implemented. Therefore the eradication of criminal acts of corruption needs to be increased professionally, intensively and sustainably because corruption has detrimental to state finances, the country's economy, and hampered national development, and because government institutions that handle corruption cases have not functioned effectively and efficiently in eradicating acts criminal corruption.

${ }^{14}$ Hibnu Nugroho, Integralisasi Penyidikan Tindak Pidana Korupsi di Indonesia, Media Prima Aksara, Jakarta, 2012, hlm. 52 
The KPK was formed with the main mission of law enforcement, namely in terms of combating corruption. The establishment of this institution was due to the idea that conventional law enforcement agencies, such as the Attorney General's Office and the Police, were deemed unable to eradicate corruption $^{15}$. Therefore it is necessary to establish a special institution that has broad and independent authority and is free from any authority ${ }^{16}$. In addition, with the increasingly sophisticated way people commit corruption, conventional law enforcement agencies are increasingly unable to disclose and bring large corruption cases to court.

According to Articles 2 and 3 of Law No. 30/2002, the KPK is a state institution that carries out its duties and authority independently and is free from the influence of any power. Eradication of corruption in accordance with Article 1 number 3 of Law No. 30/2002 is a series of actions to prevent and eradicate criminal acts of corruption through efforts to coordinate, supervise, monitor investigations, investigations, prosecutions, and hearings in court hearings, with community participation based on applicable laws and regulations ${ }^{17}$.

Corruption in Indonesia continues to penetrate into the joints of people's lives, at least it can be felt in everyday life without exception in the banking sector. Banking institutions in the Indonesian economy occupy a strategic position. The national and international economies are developing very quickly, competitively and integrated, thus creating increasingly complex challenges and demanding increasingly advanced systems. The function of the bank is not just an institution that only collects funds from the community and redistributes it in a variety of financial intermediary facilities, but has developed into a pillar of economic, social, and even political growth ${ }^{18}$.

The intention to eradicate corruption was pushed throughout Indonesia. This is indicated by the increasing financial / asset saved by the state every year in the prevention and completion of corruption cases. A number of implementing and supporting institutions for corruption eradication were formed. Among other things, in addition to the KPK, the Financial Transaction Reports and Analysis Center has now also been established, as well as the Witness and Victim Protection Agency.

The President has also issued a number of instructions and directives for the prevention and eradication of corruption, for example the Presidential Instruction (Inpres) 5 of 2004 concerning the Acceleration of Eradicating Corruption in Indonesia. Through this Inpres, the President mandated various strategic steps, including in the form of the National Action Plan for the Eradication and Eradication of Corruption (RAN-PPK) 2004-2009. The document which was announced as a reference for parties in the Central and Regional Governments in combating corruption emphasizes prevention and enforcement efforts, as well as a guideline for the implementation of monitoring and evaluation.

\subsection{Corruption Prevention by the KPK}

The KPK in eradicating corruption uses two ways, namely acting (repressive) and preventing (preventive) ${ }^{19}$. The eradication of corruption, which is merely an act of repression (repressive), will not be able to overcome corruption to its roots. Preventive measures are also needed that function to prevent the growth of corruption in the future. Therefore, in addition to carrying out repressive steps, the KPK also carries out preventive measures. Included in preventive steps include; registration and examination of

\footnotetext{
${ }^{15}$ Ibid.

${ }^{16}$ Ibid., hlm. 56.

${ }^{17}$ Ermansyah Djaja, Memberantas Korupsi bersama KPK, Sinar Grafika, 2010, Hlm. 254

${ }^{18}$ Marwan Effendy, Korupsi dan Pencegahan, Timpani Publishing, Jakarta, 2010, hlm. 1

${ }^{19}$ Deni Setiawan, KPK, Pemburu Koruptor; Kiprah Komisi Pemberantasan Korupsi dalam Memberangus Korupsi, Pustaka Timur, Yogyakarta, 2008, Hlm. 30.
} 
LHKPN, gratuities, education and community services, research and development of monitoring and development of collaborative networks ${ }^{20}$.

The precautionary measure for corruption is very direct from Law Number 30 of 2002. Article 6 regulates that; The Corruption Border Commission has a duty; d. conduct preventive actions for corruption crimes ".

The concept of crime prevention (crime prevention) according to The National Crime Prevention Institute; "Is defines crime prevention and recognition of crime and the initiation of some action to remove or reduce $i t^{\prime \prime 21}$. So, crime prevention is the process of anticipating, identifying and estimating the risk of crime occurring and initiating or a number of actions to eliminate or reduce crime.

Preventive action is a preventive measure, namely steps taken to prevent corruption. There is a saying that "prevention is better than cure", prevention is better than cure. These preventive actions need to be carried out in all government agencies especially government agencies that are prone to corruption. There needs to be a strict system of supervision by supervisory institutions both parliamentary oversight carried out by the House of Representatives and the Regional People's Representative Council, internal supervision carried out by the Inspectorate General (close supervision) and judicial supervision carried out by the Police and Prosecutors' Offices.

Repressive actions or law enforcement actions are actions taken against people or perpetrators who have committed corruption. This legal action must not be indiscriminate or selective. Anyone who is suspected of committing a criminal act of corruption must be processed in court. Even in Indonesia there has been a kind of "precedent" that even a "besan" from the President can be prosecuted and sentenced for committing a criminal act of corruption. The thing that can also be considered to cause a deterrent effect on the perpetrators of corruption is the type of criminal offense. The rise of corruption in Indonesia is likely due to the imposition of a criminal offense that does not have a deterrent effect, for example there has not been a corruptor who has been sentenced to death as in China ${ }^{22}$. A maximum of twenty years and even no one has been sentenced for life.

Regarding the composition of Human Resources (HR) according to KPK organizational units can be seen in the following table;

\footnotetext{
${ }^{20}$ Deni Setiawan, Op-cit, Hlm. 32.

${ }^{21} \mathrm{O}$ 'Block L. Robert, Secure and crime Prevention, CV Mosby Company, St Louis, 1981. Hlm. 3.

${ }^{22}$ A Beijing court sentenced China's former railroad minister Liu Zhijun to death for alleged bribery and abuse of authority in a corruption scandal.

http://www.republika.co.id/berita/internasional/global/13/07/09/mpndd6-karena-korupsi-cina-hukum-mati-mantanmenteri-kereta-api. accessed on September 5, 2013
} 
HR Composition Table According to Organizational Unit

\begin{tabular}{|l|c|l|}
\hline No & Organizational Unit & Total \\
\hline 1 & Leader & 5 \\
\hline 2 & Advisor & 2 \\
\hline 3 & Prevention & 134 \\
\hline 4 & Prosecution & 190 \\
\hline 5 & Information and Data (INDA) & 127 \\
\hline 6 & $\begin{array}{l}\text { Internal Supervision and Public Complaints } \\
\text { (PIPM-Pengawasan Internal dan Pengaduan Masyarakat) }\end{array}$ & \\
\hline 7 & Secretariat General(Setjen) & 143 \\
\hline & Total & 674 \\
\hline
\end{tabular}

Laporan Tahunan (LAPTAH) KPK, Tahun 2017, KPK, Jakarta, hal. 57

In carrying out the task of preventing corruption, the KPK has the authority ${ }^{23}$;

(1) Register and examine reports on assets of state administration;

(2) Receive reports and determine gratification status;

(3) Carry out anti-corruption education programs at every level of education;

(4) Designing and encouraging the implementation of a nationalization program to combat corruption;

(5) Conduct anti-corruption campaigns to the general public;

(6) Conduct bilateral or multilateral cooperation in eradicating criminal acts of corruption.

From the KPK Annual Report 2017, it was revealed that the DKI Jakarta Regional Election was a pilot project for the implementation of corruption prevention programs through the supervision of election administration. This activity starts from the nomination process until the chosen candidate. Before the nomination process, the KPK held discussions with the DKI Jakarta Election Commission to ask for input from the Election Commission, regarding what steps could be taken by the KPK to help the DKI Election Commission in the democratic process. Including a series of prevention of corruption in the election process, the KPK also conducted verification and clarification of the candidates' wealth reports. In this case, the KPK, among others, went directly to the residence of governor candidates and vice-governor candidates to cross check the LHKPN that had been reported ${ }^{24}$.

\section{References}

Andi Hamzah, Pemberantasan Korupsi Melalui Hukum Pidana Nasional dan Internasional sajawali Pers, 2012.

Deni Setiawan, KPK, Pemburu Koruptor; Kiprah Komisi Pemberantasan Korupsi dalam Memberangus Korupsi, Pustaka Timur, Yogyakarta, 2008.

Ermansyah Djaja, Memberantas Korupsi Bersama KPK, Penerbit Sinar Gerafika, Tahun 2010.

${ }^{23}$ Ermansyah Djaja, Memberantas Korupsi Bersama KPK, Penerbit Sinar Gerafika, Tahun 2010, Hal. 262.
${ }^{24}$ Komisi Pemberantasan Korupsi, Laporan Tahunan (LAPTAH) KPK, Tahun 2012, KPK, Jakarta, hal. 23 
Ermansyah Djaja, Memberantas Korupsi bersama KPK, Sinar Grafika, 2010.

Edward Omar Sharif Hiariej, Pembuktian Terbalik Dalam Pengembalian Aset Kejahatan Korupsi, Pidato Pengukuhan Jabatan Guru Besar pada Fakultas Hukum Universitas Gadjah Mada pada tanggal 30 Januari 2012 di Yogyakarta.

Hibnu Nugroho, Integralisasi Penyidikan Tindak Pidana Korupsi di Indonesia, Media Prima Aksara, Jakarta, 2012.

Jimly Asshiddiqie, Pengantar Ilmu Hukum Tata Negara Jilid II, cet. 1, (Jakarta: Konstitusi Press, 2006.

Komisi Pemberantasan Korupsi, Laporan Tahunan (LAPTAH) KPK, Tahun 2012, KPK, Jakarta. 2012.

Marwan Effendi, Korupsi dan Strategi Nasional Pencegahan Serta Pemberantasannya, Referensi, Jakarta, 2013.

Marwan Effendy, Kekuasaan Kejaksaan RI (Posisi dan Fungsinya dari Prespektif Hukum), (Jakarta: PT. Gramedia, 2005.

Mahmuddin Muslim, Jalan Panjang menuju KPTPK, (Jakarta: Gerak, 2004.

Marwan Effendy, Korupsi dan Pencegahan, Timpani Publishing, Jakarta, 2010.

O ‘Block L. Robert, Secure and crime Prevention, CV Mosby Company, St Louis, 1981.

Romli Atmasasmita, "Perspektif Pengadilan Korupsi di Indonesia", (Makalah disampaikan dalam seminar tentang Pembentukan Pengadilan Korupsi yang diselenggarakan oleh KHN dan BPHN, Jakarta, 30 Juli 2002Saldi Isra, Makalah, Peran Perguruan Tinggi dalam Pemberantasan Korupsi, disampaikan dalam Seminar Sehari "Penanggulangan Tindak Pidana Korupsi Melalui Pendidikan Tinggi Hukum, dan Launching Pembukaan Program Kekhususan Anti-korupsi", diadakan oleh Fakultas Hukum Universitas Tamansiswa-Padang, di Hotel Inna Muara, Padang, 14 Maret 2009

Syaiful Ahmad Dinar, KPK dan Korupsi (Dalam Studi Kasus), Cintya Press, Jakarta, 2012.

Sumali, Reduksi Kekuasaan Eksekutif di Bidang Peraturan Pengganti Undang-Undang (PERPU), (Malang: UMM Pres, 2003.

Yopie Morya Immanuel Patiro, Diskresi Pejabat Publik dan Tindak Pidana Korupsi, Keni Media, Bandung, 2012.

Syaiful Ahmad Dinar, KPK \& Korupsi (Dalam Studi Kasus), Penerbit, Cintya Press - Jakarat, Tahun 2012.

\section{Copyrights}

Copyright for this article is retained by the author(s), with first publication rights granted to the journal.

This is an open-access article distributed under the terms and conditions of the Creative Commons Attribution license (http://creativecommons.org/licenses/by/4.0/). 